\title{
Mind Mapping Strategy in Integrative Information Services to Improve Student Career Plan
}

\author{
Hijrah Eko Putro ${ }^{1 *}$, Muhammad Japar ${ }^{1}$

\begin{abstract}
${ }^{1}$ Faculty of Teacher Training and Education, Universitas Muhammadiyah Magelang, Magelang, Indonesia ${ }^{*}$ Corresponding author. Email: hijrah.ekoputro@ummgl.ac.id
\end{abstract}

\begin{abstract}
The objectives of the study are: Know the level of career planning of students in Muhammadiyah High School and know the effectiveness of integrative information services with mind mapping strategies to improve career planning of high school Muhammadiyah students. The population in this study is a grade III student of Muhammadiyah Salaman High School amounting to 25 students used for example research. The design in this study uses pre-Experimental: one group Pretest-posttest design using saturated sampling. Data analysis techniques used paired sample T-test with considering that in research using one free variable (independent variable). The results of the effectiveness of the research test is an increase in student career planning through integrative information services with mind mapping strategies. The student career planning level has improved after following integrative information services with mind mapping strategies. This is evident from the increasing outcomes of student career planning before and after given integrative information services with a $26 \%$ mind mapping strategy and reinforced through the effectiveness test using $\mathrm{T}$ Test which shows the data significance $(0.000)<0.05$.

Keywords: mind mapping, integrative information services, student career plan
\end{abstract}

\section{INTRODUCTION}

Career planning is a person's effort to prepare in reaching for a future, especially about a career, a high school student is in good confidence to start showing his interest in a job. Institutionally, the important high school position is to prepare learners to continue to higher education level, but in reality only some high school graduates $(56.9 \%)$, who continued his education to college, this means that most high school graduates are not able to continue their studies to the college, it can be suspected that the high school graduates who did not continue the education into the world work without the skills required by the community and the working world [1]. Factors that can cause them to not proceed to higher education, including: the economic inability of parents to finance, in addition to incomprehension in determining the continuing education also become their factor for more continuing education. This can actually be solved by various parties: the school works with parents, and non-formal education institutions such as courses and trainings in conducting coordination to help students out of problems relating to educational options and skills in the workforce.

A factor in the low understanding of the students' career planning can be a lack of the career information they get, the earliest consequences that students feel are the confusion in determining the choice of majors and further study to the colleges., as well as students who decide to work at the end of high school, they feel the confusion of choosing a job that suits his circumstances both in terms of talent, interests and skills that the students have. Lack of information or knowledge of this career is one of which is due to lack of introduction of guidance or career services and career assessment thus impacting students' ineness in determining their career choices [2].

Based on a preliminary pre-research results to teacher guidance and counseling at SMA Muhammadiyah Salaman Magelang Regency, from the results of interviews and observations concluded that weakness in the delivery of career services are still conventional

Efforts made to help students to improve the career plan required a proper strategy so that students will be able to act and determine the direction of ability that corresponds to student characteristics. Integrative Service with the mind mapping strategy to be developed is expected to develop the skills and development of students ' abilities.

Integrative Information Services the Mind mapping method is chosen as one way in the implementation of counseling services to improve student career planning. Because the mind mapping method has the advantage is; a) students are able to make a plan, b) active communication, c) be creative, d) Save time in learning planning, e) can solve the learning problem, f) can help focus, g) can help students to compile and explain mind own, h) can help students to remember better, i) help students learn more quickly and efficiently, j) help students see their overall visualization, so that students will be more attractive and aroused to Improve career planning [3].

\section{METHOD}

The method in this study was the quasi experiment, with the pretest-posttest design. The students measured the characteristics of self-understanding using scale career planning. The entire research subject was incorporated into 
one group i.e. the experimental group without a control group (One Group Pretest-Posttest Design). The experiment Group was given the information service Integrative Mind Mapping strategy [4]. The measurement plan can be seen in Table 1.

Table 1 Research measurement plan

\begin{tabular}{|lccc|}
\hline Group & Pretest & Treatment & Posttest \\
\hline Experiment & $O 1$ & $\mathrm{X}$ & $O 2$ \\
\hline
\end{tabular}

Notes:

O1: Pretest

O2: Posttest

$\mathrm{X}$ : Treatment of Mind Mapping (integrative information Services)

This research, the type of sample used is saturation sampling. The subject of this study was determined by high school students of Muhammadiyah Salaman.

\section{RESULT AND DISCUSSION}

\subsection{Hypothesis Test}

This analysis is aimed at proving or testing the hypotheses that were previously present. The technical analysis of data using the help of SPSS version 23.0 to simplify the count of data obtained. Analysis of the research data is with the following stages of analysis processing: Once the research data is obtained both the pre-test and post-test data, the next step is to do the data analysis. Data analysis is used to test the hypotheses submitted earlier. The results of the hypothesis test will then be used as a discussion of the problem. Paired Sample T-Test is a test conducted against two pairs of samples (Paired). A paired sample is interpreted as a sample of the same subject, but has two different treatments or measurements. Test the effectiveness of integrative information Services with Mind Mapping strategy to improve career planning with statistic parametric through test paired samples T-Test. Calculations using SPSS 23.0 calculation result can be shown as table below:

Table 2 Calculation result of paired sample t-test

\begin{tabular}{|ccc|}
\hline $\mathbf{t}$ & df & Sig.(2-tailed) \\
\hline-7.589 & 24 & .000 \\
\hline
\end{tabular}

Based on the results of the calculations in the table above, it can be known that Tcount $(-7.589)<$ ttable $(-2.064)$, so Ho (zero hypothesis denied) so that it can be concluded that there is a difference in career planning of the student between before and after implemented Integrative Information Services with Mind Mapping strategy to improve career planning.

Second decision-making is based on significance, it can be known that the significance of the table of 0.000 is smaller than 0.05 then Ho rejected and Ha accepted. In conclusion, there is a difference in the career planning of students before and after implementation of integrative information services with Mind Mapping strategy, so that the integrative information services with Mind Mapping strategy for effective to improve career planning of high school students Muhammadiyah Salaman. To conclude effectively whether the information service has been done against the respondent, the researcher bases on the arguments built, namely: the service can be said to be effective if the respondent's dominant increased career planning score after treatment. To be able to conclude the effectiveness of services integrative information with Mind Mapping strategy that has been done against respondents, researchers base on the arguments built, namely: services can be said to be effective if the respondent dominant a career planning score after treatment.

In the results of the analysis proved there is an increase in the average career planning students in the initial evaluation (pre-test) and final evaluation (post-test), so that there is the influence of the service integrative information with Mind Mapping strategy. Evidence of increased career planning students can be seen in the score table or comparison between pre-test and final evaluation (post-test)

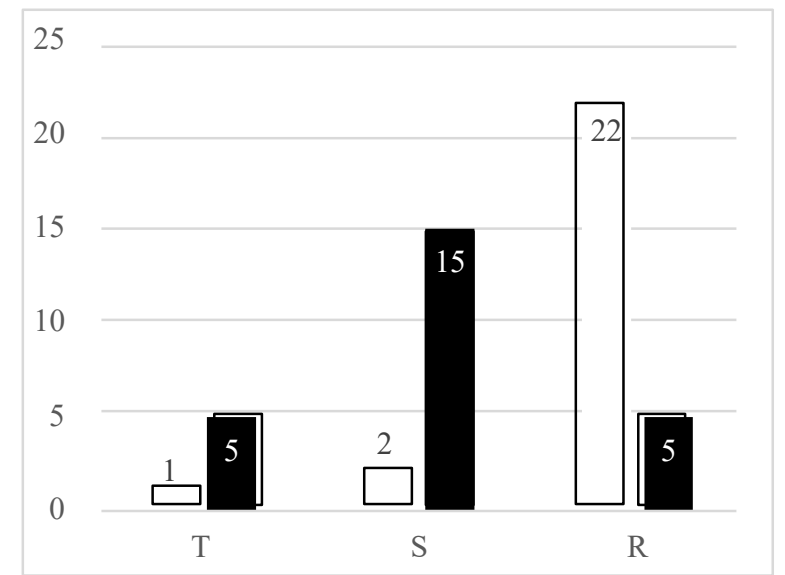

Figure 3 Histogram scale comparison before and after treatment

Further research results relate to the student career planning overview. The level of understanding of career students who belong to groups before and after obtaining integrative information services with Mind Mapping strategy has increased by $26 \%$. The test results of the effectiveness of this research are: Student career planning before given integrative information services with Mind Mapping strategy is 25 students consisting of 1 student with a high category, 2 students with a medium category, 22 students with low category, career planning students after given integrative information services with Mind Mapping strategy is 25 students consisting of 5 students with high category, 15 students with medium categories and 5 with low categories.

\section{CONCLUSION}

Students are expected to be more sensitive to situations and conditions so that they can improve student career planning. With the provision of integrative information services with Mind Mapping strategy, students become more eager to learn and the learning process becomes more meaningful. 


\section{ACKNOWLEDGMENT}

St the student career plan is increased and the service rendered significantly affects. So, the role of BK teachers can be recognized by students and parents

Information services are one of the most important forms of service organized by the school. Learning activities conducted in the school, certainly cannot escape from the teaching and learning activities also factors that can affect the teaching process of learning among other students, educators, advisers, curriculum, methods Also facilities and infrastructure. In this research author's lifting method is used is the "Integrative Information Service Strategy mapping is effective to improve the planning of a class III career proved to be with the change or increase in the scores of students after Perform treatment or treatment. This conclusion is based on the difference in initial evaluation score and final evaluation, where there is an increase in career planning level of students before and after being given a mind mapping-based integrative information service by $26 \%$.
The funding source of the research came from the university's internal funding program, which is the Batch II Revitalization Vision Programme (PRVI).

\section{REFERENCES}

[1] "Program Pendidikan Life Skills Bagi Siswa Sekolah Menengah Atas di Wilayah Pesisir," J. Pendidik. dan Kebud., vol. 13, 2007.

[2] M. Lathifah, "Pengaruh Layanan Informasi Bimbingan Karir Terhadap Kemandirian Memilih Karir Siswa," University Press UNIPA, 2011.

[3] S. P. Lukita Octavia Lukman Putri, "Mind map sebagai model pembelajaran menilai penguasaaN," no. March, 2017.

[4] M. Setiyo and U. M. Magelang, Teknik Menyusun Manuskrip dan Publikasi Ilmiah Internasional, no. February. 2019. 